\title{
STAROBINSKIY LA LITERATURA DEL MUNDO, EN UN SIGLO CRÍTICO
}

\author{
Mauricio Jalón
}

(Universidad de Valladolid)

Jean Starobinski, La beauté du monde. La littérature et les arts, París, Éditions Gallimard, 2016, 1.344 pp., con «L'œuvre d'une vie», pp. 17-221, de Martin Rueff. ISBN: 978-2-07-014560-7

Con un título casi provocador hoy, Jean Starobinski (Ginebra, 1920) publicó su último libro, La beauté du monde, cuando cerraba otro extenso volumen para 2017. Su elaboración estuvo ligada a la de tres valiosísimos tomos de 2012: L'encre de la mélancolie, con todas las modalidades médico-literarias de la tristeza (incluyendo un gran texto sobre el Quijote); Accuser et séduire. JeanJacques Rousseau, último estudio sobre la tensión rousseauniana —ese poder de su resentimiento que empezó a captar en La transparencia y el obstáculo (1957)—; y al fin Diderot, un diable de ramage, obra sobre su otra figura predilecta en las Luces, donde ordena el especial "griterío» diderotiano que le ha acompañado cuarenta años. A estas cuatro grandes recopilaciones de textos, nunca recogidos en libro, hay que sumar en 2013 Les approches au sens, tomo teórico que renueva La relación crítica (1970), pues la búsqueda del sentido no es ajena a este serio intérprete textual (y social), a un Starobinski que se expone en la escritura, y que expone sus atisbos sin esconder sus dudas.

Toda esta ordenación por capas de sus ensayos sueltos era una promesa recurrente. Ahora se vincula a la donación total de sus «fondos» a los noventa años. En 2011, los cuarenta mil libros dados por Starobinski a la Bibliothèque nationale suisse (Berna), se unieron a sus ricos archivos literarios, ofrecidos desde 2004. Sin olvidarnos del tamaño de ese legado civil, su contenido evidencia una variedad y un refinamiento propios de sus intereses ramificados y de la calidad singular de su escritura. Manuscritos, esbozos, planes y correspondencia — jugosa, por ser él un gran cultivador del género epistolar-, están abiertos al disfrute público, y se 
ven orientados anualmente, desde 2008, por el Bulletin du Cercle d'études internationales Jean Starobinski.

De entrada, con las doscientas páginas introductorias de Rueff, disponemos de una biografía suya, objetiva y sintética. Rougemont escribió, en 1985, sobre su amigo más joven: «no me sorprendería mucho que nos diera un día ese libro sensato y de aterciopelada sabiduría en el que, al hablarnos del mundo en que vive, y no ya con el pretexto de ser autor, nos hiciese ver su verdadero yo». Si esta presunta 'obra maestra' de Starobinski no ha llegado, libros breves —como La parole est moitié à celuy qui parle... (2009) y Notre seule, notre unique jardín (2011)—, o muchos textos de La beauté du monde dejan entrever una vida familiar marcada por el exilio (al igual que tantos maestros suyos), así como un largo trayecto de amistades, encauzada por poetas y teorías muy dispares. Sus libros son autobiográficos — acota— dado que quien se olvida de tomarse como referencia lo más completamente posible «no puede evitar traicionarse, manifestarse».

Con letra apretada, La beauté du monde contiene más de cien ensayos, referentes al mundo contemporáneo, por contraste con sus monografías, que se sitúan entre los siglos XVI y XVIII: sus bellas entradas con Ronsard y con Chénier son testigos de esas dos centurias. Las dos partes principales del tomo son, por un lado, "La literatura y la belleza del mundo» (subdividido en 'La poesía y la existencia', 'Los tiempos del poema' y 'La fuerza de la prosa'), y, por otro, mucho más breve, sobre pintura y música: «Las artes y la belleza del mundo» ('Mirar', 'Escuchar', 'Los tiempos de la escucha'), ya en las pp. 1.015-1.281. Algunos son muy tempranos (en el inseguro 1943 era ya un militante cronista); y luego no ha pretendido cambiar. En conjunto expone su gusto por la poesía y las poéticas incisivas pero claras, su pasión por las revistas y los intercambios culturales. Sus mil páginas —asociadas casi siempre a nombres propiosgiran en torno a la idea literaria y artística de belleza, pero también a la de su imposibilidad, desgaste y fractura —nuestra otra belleza, tan compleja-, seguramente atravesada por la tensión unidad / fragmentación, que desde los primeros modernos llega hasta los románticos. La atracción simultánea hacia tendencias contradictorias afecta a sus análisis, de acuerdo con los autores que más frecuentó. En su primer Rousseau, decía Starobinski (y lo asumía) que su «aspiración a la unidad sigue estando insatisfecha siempre: indica la dirección de un deseo y no una posesión segura»; puesto que las fuerzas adversas combaten sin descanso permanecemos en 
el desgarramiento y la división, pero sin ambivalencia moral pues él es un moralista, y busca las sendas de la verdad propias de cada texto.

En general, hay en su «prosa de ideas» dos líneas maestras: entre los clásicos modernos, una que va de Montaigne a Rousseau, y otra, contemporánea, de Baudelaire a Kafka, como poco. Juntas atestiguan un gusto por la introspección, un interés por el presente y la problematización de ciertos textos clave a lo largo de los años. En este libro destacan enseguida sus catas en la obra de Kafka, iniciadas en 1943, con una versión francesa de sus prosas que pudo haber convertido en un librito autónomo (pp. 939-980). En sus cinco ensayos, aborda la destrucción del hombre y la invasión del mal en su tiempo; los interiores kafkianos, tan enrarecidos y grises; luego, sus lugares de vida apretada y provisional (como sucedía, dice, en Crimen y castigo); la doble posición de Kafka mirando siempre a través de los dos lados de una ventana; y, en fin, su doloroso e intranquilo judaísmo (la religión primera de los padres de Starobinski).

Con todo, el campo poético es fundamental en La beauté du monde, y además la lengua francesa es dominante aunque concluya con dos páginas sobre Celan y su 'voz de superviviente'. Los poetas son Baudelaire, Mallarmé y Lautréamont, un enfático Claudel, Valéry por tres veces visitado (pp. 591-626), y Saint-John Perse, que suponen dos grupos nada insólitos; luego Breton, brevemente, su mentor Jouve (con toda una notable y escondida monografía, pp. 659-783), Char y Caillois. Se cierra esta panorámica personal con dos cuidadores de las palabras del mundo. Por un lado, está la poesía esencial de Bonnefoy, muerto al aparecer este libro; fue un amigo cercano que le invitó a dar ocho clases en el Collège de France (1987-1988), y que trabajó como él sobre Goya, como se ve en La beauté du monde. Si este poeta vertió a Shakespeare de modo impresionante, Jaccottet, por su lado, hizo lo propio con Homero y Platón, Dante y Góngora, Hölderlin y Leopardi, Mandelstam, y todo Musil (Starobinski quiso traducirlo de joven). En «Ph. Jaccottet traducteur», uno de sus dos homenajes, sugiere que la pasión por las lenguas, capaz de unir pensamiento exigente y ejercicio equilibrista con cada palabra «corresponde a la mejor acepción posible de la filología». También la amplitud de lenguas manejadas por Starobinski (alemán, inglés, italiano, castellano, aparte del polaco y el ruso que oye en su familia), es otro rasgo suyo de apertura y de verdadero saber.

Entre los tres primeros poetas, Baudelaire ha estado siempre en este discípulo de Raymond —De Baudelaire al surrealismo es de 1933-, y tendríamos otro hermoso volumen suyo con haber 
impreso esas páginas, 368-559. Estos quince textos ofrecen toda un visión imantada y lacerante que nos afecta mentalmente, como vieron Proust o Benjamin: es el diapasón de la gran ciudad y del dédalo callejero, es el que guarda las rimas y las homofonías como un orden contra la destrucción. Baudelaire, con sus enumeraciones y alegorías, accede a la madurez obsesivamente y se abisma en la consciencia de la finitud. El poeta espectral y luminoso, principesco y bufón con un punto antisemita, es un autor ciclotímico, un comparador agresivo o soñador. Es tan actual que él renovó la 'memoria de Troya', esa destrucción visionaria que articula la Eneida y desde Dante llega a la poesía actual.

Starobinski repasa aquí menos al Baudelaire crítico de arte, fustigador y narcisista, que siente la impotencia creadora y la muerte del artista. Ya en su juventud Starobinski, aunque no era cinéfilo, quiso y pudo sumergirse a fondo en El Prado, resguardado entonces en Ginebra por la II República, y trabajó de cerca con el editor de arte Skira. Buena parte de su obra carece de imágenes. Pero hay grandes excepciones; la más reciente fue Largesse (1994), realizado con el Louvre como catálogo grande y desconcertante sobre el don. Y La beauté du monde —solo con fotos de familia—, dedica cien páginas a la pintura, no sólo de Guardi, Piazzetta, Goya y Füsssli, o de Van Gogh y Pizarro sino también de contemporáneos (Balthus, Michaux, Garache), y unas más a arquitecturas desde el Renacimiento o a la escultura que rebrotó en la modernidad. Sus análisis finales remiten a La invención de la libertad (1964), o a 1789, los emblemas de la razón (1973), ambos bien ilustrados, pues su siglo XVIII es también muy visual.

Queda por evocar su propia empresa interpretativa, carente de método rígido, que multiplica los interrogantes y elude los recursos prefijados. Aunque de modo en verdad personal, su desciframiento es deudor de todo un siglo humanístico, quebrado — y esparcido por el mundocuando él se lanzó a escribir. Tras él está la crítica literaria francófona (Béguin, Raymond, Poulet, Rousset), los grandes romanistas alemanes del siglo XX, los otros exiliados 'artísticos' —como Panofsky y Saxl—; todo sin olvidar a los médicos-historiadores en su trienio en Baltimore, o al ilustrado Cassirer y a filósofos más bien existencialistas. Pero solo en la misma lectura de cada pieza —así en La beauté du monde- es cuando se percibe una fuerza y originalidad que excede cualquier comentario rápido.

Extraño al estructuralismo, Starobinski convivió con protagonistas de esa corriente, y no dejó de leer sus creaciones y análisis literarios. De hecho, en este libro retoma el diálogo Jakobson 
/ Lévi-Strauss, a propósito de Les chats de Baudelaire, y recuerda a su amigo Barthes, que estuvo un semestre en Ginebra enseñando, hacia 1971, y ambos en una doble conferencia mostraron sus diferencias de mirada, aunque sus hermenéuticas dejan entrever un cuidado freudismo: desmenuzaron dos textos bíblicos, la «Lucha con el ángel» el primero, y el poseso de Gerasa el segundo (La posesión demoníaca, 1974). Es más, la parte musical de La beauté du monde se cierra con el teorizador de la escritura, gran músico de las ideas, provisto de cierto toque de «perversidad muy contemporáneo», dice Starobinski. La estilización personal de Barthes le resultó sugestiva.

En su caso, 'interpretativo' remite intensamente a 'amistoso', como se ve bien en La beauté du monde. Los que lo han tratado conocen su calor y entrega personal. Supo describirlo, en la 'otra lengua' románica de Starobinski, el gran Eugenio Montale, que lo trató de joven: «ll ginebrino. / Il musico della parola / ha un percorso esemplare, / egli ci fa più attenti / anche a una sola nota» (Le poème d'invitation, 2001). Sí, cada nota de su estilo musical nos vuelve más perceptivos. 